\title{
The world voyage of James Keir Hardie: Indian nationalism, Zulu insurgency and the British labour diaspora 1907-1908
}

\author{
Jonathan Hyslop \\ Wits Institute for Social and Economic Research, University of the Witwatersrand, \\ Johannesburg, South Africa \\ E-mail: hyslopj@wiser.wits.ac.za
}

\begin{abstract}
In 1907-1908, the British labour leader, James Keir Hardie, made a round-the-world tour, which included visits to India, Australasia and southern Africa. The support for Indian nationalism which he expressed precipitated a major international political controversy, in the course of which Hardie came under severe attack from the Right, both in Britain and in her colonies. In southern Africa, the issue, combined with Hardie's earlier criticism of the repression of the 1906 Bambatha rising in Natal, sparked rioting against Hardie by British settlers during his visit. This article seeks to show how Hardie's voyage illuminates the imperial politics of its moment. Hardie's journey demonstrates how politics in the British colonies of his era took place not within local political boundaries, but in a single field which covered both metropolis and colonies. The article is a case study which helps to illustrate and develop an argument that the white working classes in the pre-First World War British Empire were not composed of nationally discrete entities, but were bound together into an imperial working class which developed a distinct common ideology, White Labourism, fusing elements of racism and xenophobia with worker militancy and anti-capitalism. The current paper refines this analysis of the politics of the imperial working class by situating it in relation to the rising force of Indian nationalism in the same period, and to the changes this development generated in the politics of the settler colonies and the imperial centre. In India, Hardie forged links with the dynamic new political mobilization that had followed on the crisis over the partition of Bengal. In doing so, he entered, as an ally, into the discursive struggle which Indian nationalists were waging for self-government. By taking a pro-Indian position he antagonized the British Right. Labourites in the white settlement colonies wanted to defend Hardie, as a representative figure of British labour, but were embarrassed by the fact that Hardie's position on India went against the grain of White Labourist ideology. In southern Africa, local leaders of British labour did opt to defend Hardie. But they did so not only at the risk of alienating their members, but also at the price of being forced into direct confrontations with anti-Hardie groupings.
\end{abstract}




\section{Introduction}

On 18 September 1907, the British Empire's most famous socialist disembarked in Calcutta. ${ }^{1}$ James Keir Hardie had, the previous year, attained the summit of his political career. $^{2}$ At the January 1906 British general election, twenty-nine members had been elected to parliament under the auspices of the Labour Representation Committee - the first substantial group of members linked to the organized working class. They had constituted themselves into a new force in national politics, the Labour Party, with Hardie as their leader. It was a triumph for the struggle for working-class political representation which Hardie had led and inspired for two decades. But by early 1907, Hardie's health was breaking down. His colleagues had eased him out of the leadership, and sent him off on a recuperative world cruise. Up to the point of reaching Calcutta, Hardie's voyage was exactly the kind of rest it was designed to be. But within days of his arrival in India, Hardie would, inadvertently, generate a political storm which would blow across the length and breadth of the British Empire. Through his two-month long grand tour of India, and the next leg of his trip, through Australasia, his critical stance towards imperial policy in India and South Africa would be the subject of controversy. And in the final, southern African, stretch of his journey, Hardie's presence would spark riotous outbursts by the settler colonists of Natal and the Transvaal.

This article seeks to show how Hardie's voyage illuminates the imperial politics of its moment. Hardie's voyage demonstrates how politics in the British colonies of his era took place not within local political boundaries, but in a single field which covered both metropolis and colonies. Importantly, the significant political relationships here were not only ones between metropolis and colony, but also lateral ones between colony and colony. ${ }^{3}$ This article is a case study which helps to illustrate and expand an argument that I have developed in several earlier papers. I have previously contended that the white working class in the pre-First World War British Empire were not composed of nationally discrete entities, but were bound together into an international working class by flows of population across the world. I also put forward the view that this imperial working class developed a distinct common ideology, which I have called White Labourism, which fused elements of racism and xenophobia with worker militancy and anti-capitalism. ${ }^{4}$ The pervasive fear of white workers in Australasia, British Columbia, southern Africa and on the ships of the British merchant marine was that they would be replaced by the cheap labour of people of colour.

1 J. Keir Hardie, India, impressions and suggestions, London: Independent Labour Party, 1909. All subsequent references to 'Hardie, India', are to this edition of the book.

2 The most scholarly overview of his life is K. O. Morgan, Keir Hardie: radical and socialist, London: Phoenix, 1997.

3 Frederick Cooper and Ann Laura Stoler, eds., Tensions of Empire: colonial cultures in a bourgeois world, Berkeley: University of California Press, 1997; Andrew S. Thompson, Imperial Britain: the Empire in British politics c1880-1932, Harlow: Pearson, 2000.

4 Jonathan Hyslop, 'The imperial working class makes itself "white": white labourism in Britain, Australia and South Africa before the First World War', Journal of Historical Sociology, 12, 4, 1999, pp. 398-421; Jonathan Hyslop, 'A ragged trousered philanthropist and the Empire: Robert Tressell in South Africa', History Workshop Journal, 51, 2001, pp. 64-86; Jonathan Hyslop, 'A Scottish socialist reads Carlyle in Johannesburg Prison, June 1900: reflections on the literary culture of the imperial working class', Journal of Southern African Studies, 29, 3, 2003, pp. 639-55. 
This was not pure delusion, for in particular times and places, employers were alive to the possibilities of labour cost reduction inherent in racial reorganizations of the work place; but inevitably, this focus on race by unions and labour parties slid in the direction of the embrace of the most rabid of contemporary racist ideologies. The Australian labour movement's key role in the adoption in 1901 by the new Commonwealth of the 'White Australia' policy, shutting out immigrants of colour, was the crowning 'achievement' of this movement; it became a point of reference for labour segregationists elsewhere in the Empire. My previous work has emphasized that White Labourism also contained an element of social critique. White workers who regarded themselves as excluded from full colonial and imperial citizenship by capitalist interests, were making a call for social inclusion by demanding that the colonial and imperial state treat them as 'white'.

In this paper, I refine this analysis of the politics of the imperial working class by situating it in relation to the rising force of Indian nationalism in the same period, and to the changes this development generated in the politics of the settler colonies and the imperial centre. In India, Hardie forged links with the dynamic new political mobilization that had followed on the crisis over the partition of Bengal. In doing so, he entered, as an ally, into the discursive struggle which Indian nationalists were waging - at that stage, for the most part, not one for the break-up of empire, but rather for the self-government of India. This struggle was largely couched in terms of Indian claims to be regarded as having the rights of fully British imperial citizens. In making this claim, the Indian nationalists were, among other things, countering the claims of white trade unionists across the empire that 'whites' were inherently more deserving of citizen rights. But they were also launching an attack against the Conservative forces at the imperial centre, who envisaged an endless period of paternalist rule in India, permanently excluding Indian political participation.

The complexity of this moment was that Hardie, driven by his own peculiar set of ethical concerns, was running against both Tory opinion in London, and against the tide of White Labourism in the British working class diaspora. By taking a pro-Indian position he antagonized the British Right, who unleashed a barrage of hostile publicity upon him.

Labourites in the white settlement colonies naturally wanted to defend Hardie, an exemplar and hero to them, against these attacks. But in Australia and southern Africa, which Hardie went on to visit after India, local white labour leaderships found themselves in a potentially awkward position in so doing. The pro-Indian sentiments of Hardie were diametrically opposed to the xenophobic ideologies they had been retailing. In Australia and New Zealand, such leaders were able to politely side-step the issue, simply by ignoring what had happened in India, and celebrating Hardie's great contributions to the British labour cause. But in southern Africa, where the young lawyer Mohandas Gandhi had recently led his first campaign of resistance in the Transvaal, anti-Indian mobilization was taking place amongst both middle-class and working-class whites. In these two colonies the local leaders of British labour did opt to defend Hardie, despite the fact that most of them disagreed with him on India. But they did so not only at the risk of alienating their members, but also at the price of being forced into significant physical confrontation with anti-Hardie jingoists. A further local complication was that Hardie's earlier attack, in the British parliament, on the handling of an African rebellion in Natal became a major feature of the polemics launched against him internationally. 
Had Hardie sailed a mere four-and-a half-years earlier, at the beginning of 1903, the British Indian Ocean world would have looked politically very different, and rather more stable. At that time, with the embarrassingly long Boer War at last over, Britain might have appeared to be at the peak of its power. Lord Milner was reshaping the Transvaal and Orange River Colony to imperial purposes. ${ }^{5}$ The Boers were apparently crushed, and Milner intended to outnumber them with British immigrants. From the Cape to the Zambezi the previous decades had seen the destruction of every African polity capable of posing a serious military threat to white power. In India, under the viceroyalty of the haughty and brilliant Lord Curzon, administrative reforms were energetically being carried out. No serious Indian political challenge to the British seemed to be on the horizon. Australia was a newly confederated bastion of Empire which had proved its loyalty in the recent war. The Royal Navy strategically dominated the Indian Ocean as it did every other of the world's seas. At the imperial centre, the fabled nonchalance with which Arthur James Balfour presided over his Conservative and Unionist cabinet may have seemed quite appropriate.

Yet the unravelling was already beginning. In 1903, Joseph Chamberlain split the British Right over his advocacy of imperial tariff protection. Chamberlain, appreciating as his colleagues did not, the challenge of German and American economic and naval power abroad, and of social radicalism at home, felt action was urgent. His solution was an interventionist state, and a closer union of Britain and her white colonies, protected by a wall of tariff barriers and shared defence. ${ }^{6}$ In the same year, Milner had agreed that the mine owners of the Rand, unable to attract sufficient numbers of African labourers to their enterprises because of the low wages they offered, could import Chinese indentured workers. The decision produced an outcry from liberals and trade unionists, in both Britain and South Africa, who on the one hand morally condemned 'Chinese slavery' and on the other, in a more racist vein characterized the scheme as one to undercut the wages of the British working man on the Rand. At the 1906 British elections, what swept the Liberals to an overwhelming victory were their warnings that tariff reform would make for high food prices and their denunciations of the Transvaal Chinese labour policy. This changed southern Africa dramatically, for the Liberals, guilt-stricken over British treatment of the Boers in 1899-1902, conferred self-government on the Transvaal, on the basis of an all-white franchise. Milner's immigration schemes had failed, a regional economic depression set in, and the subsequent election produced a clear majority for the Boer Het Volk party, led by General Louis Botha, who was ably assisted by the wily Jan Smuts. Although Botha and Smuts proved surprisingly favourably inclined to both the Empire and the mine owners, Britain had permanently lost the political initiative in the southern African sub-continent. ${ }^{7}$

In India, equally portentous changes had occurred. In 1905, Curzon accepted proposals for the partition of the vast and populous province of Bengal into two new provinces. Although Curzon himself largely seems to have seen this measure as a question of bureaucratic rationality, there is no doubt that for much of senior British officialdom the advantage of the measure was that it contributed to a strategy of divide and rule. The largest, most

5 Shula Marks and Stanley Trapido, 'Lord Milner and the South African State', History Workshop Journal, 8, 1979, pp. 50-81.

6 P. T. Marsh, Joseph Chamberlain: entrepreneur in politics, New Haven: Yale University Press, 1994.

7 Hyslop, 'Imperial working class'. 
dynamic, and most politically restive intelligentsia in India were the bhadralok of Bengal, centred on Calcutta. This educated Hindu middle class were loathed by British officialdom, and partition was seen as a means of diluting their influence. In the new East Bengal, where most of the peasantry were Muslim, Hindus would become a religious minority. In the new West Bengal, the bhadralok would be offset by a large proportion of non-Bengali speakers in the population. The policy had quite the reverse effect to what was intended. The bhadralok and the Hindu landowners mobilized on an unprecedented scale to oppose partition. The movement used the tactic of promoting swadeshi-locally produced goods, especially textiles - and boycotting imported products. British goods were burned on bonfires, educational institutions were boycotted and alternative 'national' schools were set up. The swadeshi movement can, arguably, be regarded as the first modernist mass nationalist resistance movement in Indian history. It raised the demand for swaraj (selfgovernment) although there was a wide spectrum of views within the movement over whether this was an immediate or a very long-term demand, and whether 'constructive' or confrontational and violent tactics were appropriate. ${ }^{8}$

When Hardie visited Bengal, the swadeshi movement was still raging, mobilizing enormous numbers of Bengalis. Yet developments as important for the future of British rule in India were taking place amongst the small (ten to twenty thousand) Indian population of the Transvaal Colony. There, the Botha-Smuts government had enacted a policy of compulsory registration for 'Asiatics', which, it was widely assumed, was the prelude to further discriminatory legislation affecting them. In Johannesburg, by late 1907, Gandhi's followers had adopted a policy of refusing to register and were awaiting state reaction. ${ }^{9}$

Natal had seen, in 1906, the so-called Bambatha Rebellion amongst the Zulus, which had been the occasion for British settler military units to unleash an orgy of violence culminating in a massacre of 'rebels' at the Mome Gorge. In reality, after the destruction of the Zulu Army by the British in the 1879 and the implosion of the Zulu social structure during the next decade there was little chance of a real threat by Zulu military action to settler rule. The rebellion was initially a fairly mild protest against the heavy-handed taxation policies of the Natal government. The use of para-military police to extract taxes then turned the revolt violent, providing the opportunity for the grotesque massacre which ensued. But white Natalians remained paranoiac about a possible repeat of the revolt. ${ }^{10}$

\section{The traveller}

James Keir Hardie was an extraordinary personality who exercised a unique influence over the early British labour movement and its international extensions. Born in Lanarkshire, he was the illegitimate child of an impoverished servant woman, Mary Keir. The boy had

8 Sumit Sarkar, The swadeshi movement in Bengal 1903-1908, New Delhi: People's Publishing House, 1994 , is the outstanding work on its subject.

9 Maureen Swan, Gandhi: the South African experience, Johannesburg: Ravan, 1985.

10 Shula Marks, Reluctant rebellion: the 1906-8 disturbances in Natal, Oxford: Oxford University Press, 1970. 
his first job at eight and became an underground miner at ten years old. During the sixteen years he spent in the mines, he kept his intellect alive through night school, a precocious devotion to reading, and an involvement in evangelical religion and the temperance movement. Hardie became involved in miners' unionism: during the 1880 s he gradually emerged as a national figure in the trade union movement. Initially, he was in the Gladstonian Liberal mainstream of the Trade Union Congress. But he then came under socialist influence and emerged as the strongest advocate within the TUC of the idea that labour should be independently represented in parliament rather than, as was then the case, falling behind the Liberal banner. In 1888 Hardie fought the Mid-Lanark by-election as an independent candidate. Though he lost, the campaign proved enormously successful as propaganda for his ideas; shortly thereafter a Scottish Labour party was formed, with broad support from trade unionists and socialists. ${ }^{11}$ In 1892 Hardie won the West Ham byelection. On the back of this success, the Independent Labour Party was established in 1893. Its work was largely responsible for securing, in 1900, the TUC's agreement to the founding of the Labour Representation Committee, thus laying the basis for the great breakthrough of 1906.

To his admirers, Hardie was a prophet as much as a political leader. His flowing rhetoric, his personal kindness, his austere way of life and incorruptibility all contributed to this image. He was, indeed, driven by a social vision derived from his early Christian formation, which gave him a profound moral commitment to a sense of human equality. This was to be important in Hardie's response to the racial politics of the Empire. Like many British socialists, Hardie had actively campaigned on behalf of the Boers during 1899-1902, but Hardie's ethical socialism propelled him, as was not the case with many other contemporary socialists, to have a deep sense of empathy for other victims of imperialism. ${ }^{12}$ What was particularly of consequence for his journey was that Hardie had publicly condemned Natal's handling of the 1906 rising, and the executions that accompanied it.

This is not however to portray Hardie as simply a saintly figure. He was by no means above using the full tactical repertoire of the practical politician. As would be seen in the course of 1907-1908, Hardie was quite capable of adapting his message to suit his audience. He was not always a consistent thinker and could take different positions on different occasions or hold two mutually contradictory positions. He was a man of his time, seeking democratization of the Empire rather than its end, and his sympathy with the oppressed could coexist with constructs derived from contemporary racial ideology.

\section{The voyage begins: July-September 1907}

On 12 July 1907 the sickly Hardie sailed from Liverpool on the Empress of Britain. ${ }^{13}$ Arriving at Quebec, Hardie commenced a rail journey across Canada, with halts at the

11 Morgan, Keir Hardie; Fred Reid, Keir Hardie: The making of a socialist, London: Croom Helm, 1978; R. Page Arnot, A history of the Scottish miners, London: George Allen and Unwin, 1955, pp. 67-70.

12 Philip Snowden, 'Foreword', in J. Keir Hardie, India, impressions and suggestions, London: Home Rule League for India, 1917, vii.

13 The Times, 13 July 1907. 
major cities along the route. This trip was gratifying and undemanding. In the various centres he was feted by local political sympathizers. ${ }^{14}$ From Vancouver, Hardie sailed for Japan. There he was received at the highest levels of government, and made a plea to the Prime Minister on behalf of imprisoned Japanese socialists. Hardie had benefited from the restful Pacific voyage: his health was reported to be 'decidedly improved'. ${ }^{15}$ Sailing on to Singapore, Hardie was made welcome there by the Governor, Sir John Anderson. ${ }^{16}$

\section{Bengal: September-October 1907}

It was from Singapore that Hardie was to sail for Calcutta. In India his idyllic and recuperative voyage was to turn into a raging international political controversy. In London, on the morning of 2 October, a truly thundering editorial appeared in The Times:

We have never doubted the power for mischief which persons like Mr. Keir Hardie possess, nor their readiness to exert those powers. By selecting Eastern Bengal as the theatre for the display of his qualities as a demagogue, he has given conclusive proof that the estimate we had formed of his criminal ignorance, or his yet more criminal recklessness, was all too just. ${ }^{17}$

In the same edition, The Times carried a report from Calcutta that Hardie had been making a tour of Eastern Bengal, and that at the town of Barisal he had made a speech in which he said he would 'do his best to assist in making India a self-governing Colony like Canada. What was good for Canadians must also be good for Indians.' The Times also told its readers that Hardie had said that 'the condition of Eastern Bengal is worse than that of Russia, and that the atrocities committed by officials would, if they were known, evoke more horror in England than the Turkish outrages in Armenia'. ${ }^{18}$ These were particularly inflammatory comparisons: Tsarist Russia was, in British political discourse, a by-word for repressive government, and the Turkish government-sponsored massacres of the Armenians in the 1890s, which were on a huge scale, and particularly sadistic in character, had sparked an international outcry. ${ }^{19}$

The British press and pro-imperial papers across the Empire took the same line. Everywhere, editorial writers invoked Kipling's short story 'The Enlightenments of Pagget MP', which satirized an interfering British liberal parliamentarian who visits India, criticizes the administration and supports the Indian nationalists. ${ }^{20}$ When rioting broke out in Calcutta

14 The Times, 29 July 1907, 6 August 1907; Morgan, Keir Hardie, p. 189.

15 The Times, 23 August 1907.

16 The Times, 16 September 1907; Hardie, India, p. 114.

17 The Times, 2 October 1907.

18 The Times, 2 October 1907.

19 Peter Balakian, The burning Tigris: a history of the Armenian genocide, London: Pimlico, 2005, pp. 33-132.

20 For an example of the use of 'Pagget' see Rand Daily Mail, 2 October 1907; for an analysis of the story see David Gilmour, The long recessional: the imperial life of Rudyard Kipling, London: Pimlico, 2003, p. 65. 
on 3 October, the imperial press widely attributed it to Hardie's statements, although there was some evidence that it was connected to a strike of cab drivers. ${ }^{21}$ Even his ILP comrades were embarrassed - they issued a statement that 'the views attributed to Mr. Keir Hardie are not those of the party'. ${ }^{22}$ Only a few radical socialists like R. B. Cunninghame Graham and Victor Grayson supported Hardie at home. ${ }^{23}$

Despite his convalescent status, Hardie had, as he later wrote, 'gone to India to study the causes of the unrest and its extent'. ${ }^{24}$ Once news of his arrival in Calcutta began to spread, Hardie was besieged by well-wishers, friends, journalists and political delegations. He found opinion in Calcutta, across the social spectrum and across the racial divide, almost uniformly opposed to partition. Curzon had been pushed from office some time earlier, but the consequences of his actions were very much alive. Moderate Indian nationalists were furious that Curzon had not consulted them on partition. Two of the four British papers in the city opposed partition. Hardie wrote that 'I gained the impression that partition had no friends outside the hide-bound official element and the semi-official and reactionary press. $^{25}$ Hardie decided to venture into the centre of upheaval because 'Everyone - European and Indian alike - strongly advised me to visit East Bengal. ${ }^{26}$ His one-week journey there appears to have been orchestrated by B. G. Tilak, an important nationalist leader from western India, with a strongly Hindu chauvinist agenda. ${ }^{27}$ Hardie was accompanied on the trip by Jagesh Chowdhuri, a Calcutta barrister and leading swadeshi activist. $^{28}$

The first leg was from Calcutta to Goalundo by rail, and from there they travelled mainly by river steamer. At Serajganj, Hardie and Chowdhuri were shown around the town by a group of local dignitaries. They went to visit the town prison. There, a British magistrate shouted at Chowdhuri and threw him out of the prison yard, receiving a tirade in return from Hardie. For Hardie, this incident illustrated 'the way in which the educated Indian is treated by a large section of Anglo-Indians' ${ }^{29}$

At Mymensingh, one of the centres of the swadeshi agitation, the government had cracked down harshly upon the town. It was in a 'proclaimed district' where no public meetings were allowed and security force personnel had been billeted upon the inhabitants. Hardie wrote that it looked like a place under siege. Every twenty yards or so armed constables were posted, whilst the ordinary policemen were also a great deal in evidence.,30

After Mymensingh, the next stop was Barisal, another town which was at the forefront of the swadeshi movement. It was here that Hardie made the statements that were to prove

\footnotetext{
21 The Star, 5 October 1907.

22 The Star, 3 October 1907.

23 The Star, 7 October 1907.

24 Hardie, India, p. 10.

25 Hardie, India, p. 11.

26 Hardie, India, pp. 9-10.

27 Morgan, Keir Hardie, p. 192.

28 Hardie, India, p. 10.

29 Hardie, India, p. 19.

30 Hardie, India, p. 22.
} 
so controversial. It was dusk when he arrived. A huge crowd had gathered to meet him, and they illuminated his way with flaming torches. Hardie was by now enraged by the Serajganj magistrate's treatment of Chowdhuri and by what he had seen of the heavy hand of government policy at Mymensingh. On the steps of the government rest house, Hardie made the speech to the crowd which The Times had reported, supporting selfgovernment for India.

By this time, Hardie had been told by swadeshi activists of alleged rapes of Hindu women by Muslims, which had accompanied the 1906-1907 communal riots. In an interview with a journalist for the nationalist newspaper Bengalee, at Barisal, Hardie compared these assaults with the atrocities in Armenia. However, when the Calcutta correspondent of Reuters wrote up his story, using the report of the interview, he attributed to Hardie the statement that the atrocities committed by officials were worse than the Armenian atrocities. This was neither what Hardie had said, nor what was stated in the account of the interview given in the original report. ${ }^{31}$ At Barisal, Hardie was also told of houses being ransacked and looted by police, and of a case where, in a nearby village, two policemen had been set up as traders, with official support, in order to break the boycott. Together with what he had seen earlier, this prompted Hardie to remark in the course of his Barisal press interview that these developments 'savoured more of Russian than of British methods'.32

When Hardie returned to Calcutta, he found himself under tremendous political pressure from the British and imperial press, and issued statements denying addressing meetings, and blaming Reuters' misrepresentations for the controversy. He also asserted that he did not mean India should be granted self-government immediately. ${ }^{33}$ Hardie was, briefly, somewhat cowed by the intensity of the storm he had aroused, but soon recovered his courage and combativeness.

Hardie's political conclusion from his visit to Eastern Bengal was that there was no desire or attempt by the participants in the swadeshi movement to overthrow British rule. Rather, Curzon's partition had brought about a legitimate and patriotic desire for reunification, and the government's brutal response was responsible for all the subsequent trouble. ${ }^{34}$ While Hardie was undoubtedly right that the British handling of the movement had been crude in the extreme, it also seems likely that swadeshi activists had manipulated his perceptions of the situation. While moderate nationalists were indeed content to accept a long period of constitutional evolution under British tutelage, the militants certainly had a more radical position than Hardie was led to believe. The militants' call for immediate swaraj, literally meaning self-rule, could be taken to mean Canadian-style self-rule within the Empire, but it could also be taken to mean total independence. Certainly the latter was the way in which it was understood by the terrorist groupings springing up under the

31 Compare The Times, 22 October 1907, giving the views of pro-imperial Calcutta journalists with the letter defending Hardie by Sir Henry Cotton MP in The Times, 29 October 1907.

32 The Times, 28 December 1907.

33 The Times, 7 October 1907; 22 October 1907.

34 Hardie, India, pp. 32, 40. 
influence of Aurobindo Ghose. ${ }^{35}$ The proponents of swaraj were considerably less accepting of continued membership of the Empire than they gave Hardie to understand.

The orchestration of his visit by the militant swadeshi leaders also blinded Hardie to a major feature of their movement. This was that the swadeshi campaign had taken on a distinctly Hindu-chauvinist and anti-Muslim character. This was not solely a product of the British practice of divide and rule, but also generated by the Hindu-exclusivist nationalism propagated by some of the swadeshi leaders. Thus the nationalist paper Amrita Bazar Patrika wrote that Hardie's arrival would 'demolish the gigantic conspiracy against the Hindus'. ${ }^{36}$ Hardie uncritically accepted the accounts he was given of Muslim assaults on Hindus. While such attacks had certainly occurred, they were on a very limited scale compared with the vicious Turkish policy toward the Armenians, and the fact that Hardie could make this comparison certainly suggests that his informants had been free with the facts. Conversely, Hardie missed swadeshi intimidation of Muslims right under his nose; Muslims in Barisal complained that their prayers had been disrupted by pro-Hardie demonstrators. ${ }^{37}$ Hardie also refused to believe the claims of Muslim merchants who told him (accurately) that swadeshi cloth was more expensive and of poorer quality than imported goods. ${ }^{38}$

\section{An Indian journey: October-November 1907}

From Calcutta, Hardie undertook a long rail journey across northern India, travelling as far as Lahore. Hardie was an indefatigable tourist, and India filled him with enthusiasm. He wrote lyrical descriptions of his view of Benares from a launch on the river ${ }^{39}$ and of the great Masjid at Lucknow, ${ }^{40}$ and was deeply impressed by the Taj Mahal. His response was more complex than simply a romantic one. Firstly, Hardie emphasized the historical precedence of Indian over western civilization and saw India's achievements as evidence in favour of Indian political claims. ${ }^{41} \mathrm{He}$ was thus firmly at odds with the emphasis on Indian incapacity which permeated contemporary British political discourse. Secondly, Hardie in no way allowed the glory of the antiquities he saw to obscure the poverty of present-day India. He was as assiduous a social researcher as he was a tourist. For example on a visit to Chaybopore, near Benares, he gathered detailed information on the dire social conditions in the village and the looming threat of famine. ${ }^{42}$

As he travelled into the north-west, Hardie was appalled by the scale of the British military presence and sceptical of the Russian threat by which it was justified. As a confirmed anti-militarist Hardie thought that the stronger the influence of the army, the more

35 Peter Heehs, Nationalism, terrorism, communalism: essays in modern Indian history, New Delhi: Oxford University Press, 1998.

36 Quoted in The Times, 2 October 1907.

37 The Times, 2 October 1914.

38 Hardie, India, p. 28.

39 Hardie, India, p. 45.

40 Hardie, India, p. 55.

41 Hardie, India, p. 45.

42 Hardie, India, pp. 49-54. 
repressive the political order was likely to be. He blamed what he saw as the army's tendency to panic over minor disturbances as responsible for much of the current imperial alarm about 'sedition' in India.

Hardie followed the railway lines in an enormous zigzag across the sub-continent via Bombay and then on south through Madras. He was impressed by the administrative and political achievements of the princely states of Baroda and Mysore, and in his writings advanced these as evidence in support of the Indian capacity for self-government. ${ }^{43}$ In contrast, attending a Taluq Board (District Council) meeting in the south, he was distressed by the way in which the senior British official bullied the Indian members. ${ }^{44} \mathrm{He}$ was also shocked by the racial segregation he encountered in railway facilities and some social events, and subsequently emphasized the demoralizing effect such practices had on the Indian elite. $^{45}$

In his book on India, published two years after the journey, Hardie was unsparing in his criticism of British rule: 'Such then, is the Government of India, bureaucratic in form, and, as a consequence harsh and exacting in all its relations toward the people. ${ }^{46}$ Hardie was convinced that the economic conditions of the peasantry had deteriorated under British rule and that this factor lay behind the prevalence of plague and famine.

But he did not favour British withdrawal from India. Rather he supported a steady democratization: genuine self-government should be granted, beginning at a local and provincial level; Indians should be admitted into senior posts in the civil service; policy reforms should promote education, craft production and peasant agriculture; petty forms of discrimination should be abolished. Eventually India would attain something like Canada's political status within the Empire. Yet there was an odd twist of racial ideology to Hardie's views. In contemporary European racial discourse the capacity for selfgovernment was often seen as racially based (and in extreme versions limited to 'Teutons' or 'Anglo-Saxons'). Some peoples had the 'racial' capacity for democracy: others did not. At the same time there was by now a widespread awareness of the linguistic connection between Sanskrit and European tongues; this being frequently elided into the idea of common 'Aryan' racial origins. In his reflections on India, Hardie brought this all together in an uncharacteristic flourish of racial nonsense purportedly supporting his political views:

For let it not be forgotten that the Indian people are of the same Aryan stock as ourselves ... This fact has a very important bearing on the question of how far the Indian people can be trusted with the right of self-government. ${ }^{47}$

At Tuticorin, in India's far south, Hardie was treated to a lively send-off with bands and carriages accompanying him. From here, he took ship to Colombo, Ceylon, where he spent a few days on the island. Hardie called on the Governor, Sir Henry McCallum, but was told

43 Hardie, India, pp. 84-81.

44 Hardie, India, pp. 74-76.

45 Hardie, India, p. 97.

46 Hardie, India, p. 78.

47 Hardie, India, p. 102. 
that McCallum was 'too busy' to see him. ${ }^{48}$ This was not entirely surprising. In the previous year, McCallum had been Governor of Natal at the time of the Bambatha Rebellion, and (although against his own better judgement) acquiesced in the settler government's decision to execute twelve rebels by firing squad. The ILP had roundly condemned him for this. Although there was some debate about whether Hardie had actually called McCallum a 'murderer' over the incident or not, the Labour leader was clearly not high on the Governor's list of desirable visitors.

\section{Australia and New Zealand: November 1907- February 1908}

Hardie sailed from Colombo on the next leg of his journey aboard the Royal Mail ship India. The vessel docked at Fremantle, Western Australia, on the morning of 26 November. ${ }^{49}$ Hardie's few days in the state included a visit to the gold-mining centre of Kalgoorlie. ${ }^{50}$ On the Australasian part of the tour, Hardie did not make much use of overland transport, instead hopping from one city to another by ship. He sailed on to Adelaide, Melbourne, and thence to Wellington. Although the Australian and New Zealand press had been largely hostile to Hardie's position on India, ${ }^{51}$ he was politely received by his opponents and rapturously welcomed by Australasian socialists. As in Canada, Hardie was honoured at a series of meetings, dinners and social events. He reported that he had 'experienced a kindness and fellowship which knew no limits'. ${ }^{2}$ Apart from a motor car accident in New Zealand - Hardie was slightly injured but recovered well - all passed off without mishap.

Hardie thoroughly enjoyed the company of Australian and New Zealand labourites, but his view of their leaders was less than enthusiastic. In New Zealand he was impressed by the eight-hour day, old age pensions and wage courts, but considered R. J. Seddon as a liberal rather than a socialist. ${ }^{53}$ In Australia, he was optimistic of the long-term prospects for a radical socialist government, but was sceptical of Labor's participation as a minority party in state governments. In his view, only in South Australia had Labor been 'fairly successful'. Hardie thought that Labor should wait until it had a clear electoral majority before trying to implement its policies. ${ }^{54}$

Hardie was critical, although in a low-key manner, of the politics of 'White Australia'. He commented that 'time alone can decide' whether the 'experiment' of keeping Australia white would succeed. But he did state quite forcefully that the Australian working class's commitment to this policy was making them vulnerable to reactionary and

\footnotetext{
48 The Times, 15 November 1907.

49 The Evening Mail, 26 November 1907.

50 The Times, 25 and 26 November 1907.

51 The Star, 4 October 1907.

52 Labour Leader, 10 April 1908.

53 Morgan, Keir Hardie, p. 196.

54 Labour Leader, 10 April 1908.
} 
anti-democratic influences. 'Certain journalists and politicians' were using the strength of 'White Australian' sentiment to 'terrorise' Australians into 'entering upon a career of militarism'. Hardie deprecated the current plans for an Australian Navy and the Deakin government's proposals for universal military training. He saw creeping militarism as potentially undermining Australian democracy, and thought the Japanese 'bogey' no real threat to either Britain or Australia. ${ }^{55}$

From New Zealand, Hardie set out again for Natal, stopping for return visits to Melbourne and Adelaide en route. His voyage from Adelaide to Durban was aboard the SS Narrung, a ship of 5,700 tons. Hardie was joined on this part of the trip by the South Australian Labour premier, Tom Price, who was on his way to visit Britain. Hardie was by now thoroughly enjoying himself at sea ${ }^{56}$ - he would need the rest.

\section{Natal and the Transvaal: February 1908}

From the moment that the controversy around Hardie's Bengal speeches had hit the Natal and Transvaal colonial newspapers, they had pilloried the Labour leader. ${ }^{57}$ By raising the issue of the treatment of Indians in the British Empire he had struck a particularly sensitive theme for British colonists in southern Africa. The regional economic depression in southern Africa was intensifying anti-Indian sentiment. Natal was implementing the tax on labourers who had completed their indentures, designed to force them out of the colony, with increased harshness. But much more important were the political events in the Transvaal. During the second half of 1907, Gandhi and his followers had continued to defy the government's requirement for them to register. Arrests followed, and on 10 January 1908, Gandhi and a group of his supporters were sent to prison. The repression of Gandhi's movement by Botha and Smuts proved completely counterproductive. It received worldwide publicity, giving Gandhi his breakthrough to international fame. The treatment of Indians in the Transvaal became a major embarrassment to the Government of India and to the British cabinet. The Transvaal government came under imperial pressure to settle. On 30 January Smuts and Gandhi negotiated a compromise; Indians would register voluntarily and the resisters would be released. Much of white public opinion considered this settlement a betrayal. So did some of Gandhi's comrades: on 10 February he was attacked by former supporters who felt he had sold out, and beaten so badly that he lay gravely ill throughout Hardie's time in South Africa. ${ }^{58}$

Thus before Hardie arrived in southern Africa, a substantial section of white opinion saw him as the irresponsible supporter of Indian nationalism. But there was also another issue over which his opinions rankled with whites in Natal and the Transvaal. Despite the comprehensive and brutally effective repression of the 1906 rebellion, there had continued to be constant settler alarm about possible future Zulu insurgency, stimulated particularly

55 Labour Leader, 10 April 1908.

56 National Library of Scotland, Edinburgh, (hereafter NLS) Emrys Hughes Papers, Dep. 176 vol. 14, Hardie to Agnes Hardie, Cummnock, 6 February 1908.

57 The Times, 7 October 1907.

58 Swan, Gandhi. 
by the assassinations of a few pro-government chiefs in Zululand during 1907. Truckling to white sentiment, in December 1907, the Natal government arrested the Zulu King, Dinuzulu. He was to face charges of offering hospitality to the rebel leader Bambatha (which he had done) and of instigating him to rise up (which he almost certainly had not). In this context, white resentment of Hardie's criticism of Natal's actions in 1906 was rekindled.

It should be said, though, that the active hostility to Hardie seems to have come mainly from middle- and upper-class British immigrants. British shopkeepers, members of volunteer colonial regiments, and supporters of pro-capitalist political groups seem to have been at the forefront of the protests against him. Afrikaners were still well disposed to Hardie for his support of their cause in the Boer War, and seem to have regarded the controversy around Hardie as a family quarrel amongst the British. Whilst the British working-class political activists were generally unsympathetic to the grievances of the Indians, their allegiance to the British trade union tradition, and their admiration for the Labour Party in the United Kingdom, meant that they had great personal respect for Hardie. Thus, although mostly strongly differing with Hardie on matters of racial politics, the Natal and Transvaal labour leaders defended Hardie, both verbally, and when required, physically. And the members of their unions and political groups seem to have acted accordingly. This did however pose Hardie with a moral dilemma. He was grateful for the support and protection of the immigrant labourites. But he also wanted to challenge their racially inegalitarian views. In the coming days, he would struggle with this ambiguous position.

On 11 February 1908, the Narrung entered Durban harbour. At his hotel Hardie gave interviews to journalists from the Natal Mercury and the Natal Advertiser. ${ }^{59}$ Hardie's initial strategy toward the press seems to have been one of damping down colonist fears about his pro-Indian and pro-African positions. In relation to India he emphasized the unreliability of the British press versions of the events involving him there. He denied 'any conscious bias in favour of the natives in South Africa', but suggested that, as in the case of the working class in England 'agitation or complaint' generally had 'a very good reason at the bottom of it'. In relation to white labour protectionism, Hardie put forward a position which took account of white workers' fears for their security of employment, while challenging the idea that job security could only be guaranteed by racist and antiimmigrant legislation. What he advocated was the defence of the existing rate-for-the-job. In this argument, if trade unionism and labour parties were strong enough to enforce the current wages paid to white workers as standard across the economy, management would have no particular motivation to eject white workers from their jobs, for black workers would be no cheaper. ${ }^{60}$

However, the interviews did not succeed in getting the local press to leave Hardie alone. Hardie defended his criticism of McCallum, and his position on wages clearly implied that unionization should extend to black workers. And he outraged the Natal Advertiser's man with his admiration for India, which drew forth a blistering editorial in the Advertiser, lambasting Hardie for failing to recognize the benefits the raj had brought to India, and

59 Frederick Hale, 'Socialist agitator, traitor to the British Empire, or angel of peace? James Keir Hardie's visit to Natal in 1908', Journal of Natal and Zulu History, 14, 1992, pp. 3-4.

60 Hale, 'Socialist agitator', pp. 4-5. 
denouncing him as an advocate of equality between 'the raw native' and 'the British artisan'. ${ }^{61}$

Soon after his arrival, Hardie linked up with the leaders of Natal's embryonic British immigrant Labour Party (NLP), which had been formed the year before. This grouping advocated virulently white labourist policies - defence of whites-only suffrage, prohibition of indentured labour, and the repatriation of currently indentured Indian labourers at the end of their indentures. The foremost advocate of this position was one of the NLP's three representatives in the Natal Legislative Assembly, C. H. Haggar. Born in East Anglia, Haggar had apparently been a brothel keeper in Australia, and had since his arrival in Natal falsely but successfully passed himself off as a medical doctor. ${ }^{62} \mathrm{He}$ was closely supported in the Legislative Assembly (LA) by London-born Nelson Palmer. ${ }^{63}$ An altogether more substantial figure was the third Labour member of the LA, John Connolly. An Irishman in his mid-thirties, Connolly had served in the British Army in India, before coming to Natal in 1897 and taking a job on the railways. In 1906 he had emerged as a leader of the immigrant railwaymen and been elected for the Klip River constituency, which included the colony's main railway town, Ladysmith, where he had a solid base of support. ${ }^{64}$ Hardie met Connolly on his first day in Durban and seems to have taken a shine to him. Connolly accompanied Hardie on most of his subsequent travels in Natal and the Transvaal.

Hardie traveled up the railway line to the Colony's sleepy capital at Pietermaritzburg. At the station he was met by a handful of friendly labourites and a hostile crowd of 500 angry white citizens. The labour supporters, directed by Connolly and Palmer, shielded Hardie from the onrush of the mob and hustled him away to a nearby hotel. The crowd loitered threateningly in the vicinity before dispersing. ${ }^{65}$ On 13 February, Hardie returned to Durban for a public meeting at the port city's Town Hall. The hall was packed; when Hardie entered he was met by such a barrage of shouts and missiles from the audience that the police decided to escort him back to his hotel. Haggar, Palmer and Connolly made valiant efforts to speak. Hardie returned and attempted to speak again, but his endeavours were once more defeated. ${ }^{66}$ Hardie believed that his opponents were not from the city's white working class, but from what he called 'the cuff and collar brigade'. ${ }^{67} \mathrm{He}$ also thought the disruption was orchestrated by members of the Natal territorial regiments who had been involved in the repression of the previous year's rising: 'It was they - the heroes who had taken part in the carnage, and whose hands still reeked with the blood then shed - who organized the opposition at Durban. ${ }^{68}$

61 Hale, 'Socialist agitator', pp. 5-7.

62 David Ticktin, Origins of the South African Labour Party, PhD dissertation, University of Cape Town, 1973, vol. 1, pp. 74-76, vol. 2, p. 467.

63 Ticktin, Origins, vol. 1, pp. 368-71.

64 Ticktin, Origins, vol. 1, pp. 367-73.

65 Hale, 'Socialist agitator', pp. 8-10.

66 Hale, 'Socialist agitator', pp. 10-11.

67 Labour Leader, 22 May 1908.

68 Labour Leader, 22 May 1908. 
Hardie spoke to members of the Durban Indian community at an enthusiastic meeting at the house of a prominent merchant (and patron of Gandhi), Daud Mohammed, in the Umbilo Road. The Natal Advertiser reported this event under the headline " Queer" Hardie visits Indians', and noted with disapproval that Hardie shook hands with the participants at the end of the meeting. ${ }^{69} \mathrm{He}$ also attended the spectacular Muharrum festival. ${ }^{70}$ Although the festival was theologically based in Islam, in the Durban migrant context, extensive Hindu participation had developed. As Goolam Vahed has shown, this reflects the way in which a pan-Indian identity was forming amongst the southern African Indian diaspora $^{71}$ - a factor which was crucial in making Natal and the Transvaal a conducive context for Gandhi's political experiments.

On 15 February, Hardie boarded a train and travelled to Ladysmith, approximately 300 kilometres northwest of Durban. At the station he was heckled by a crowd of about 200 antagonists. In the evening, Hardie spoke in the crowded Railway Institute, at a meeting of about 500 people. ${ }^{72}$ Although the crowd was divided, the meeting was on balance a victory for Hardie - he wrote that; 'a couple of lawyers tried their hand at the dirty work, but the followers did not care to face the burly railwaymen who organised the meeting'. ${ }^{73}$ Opponents did however break the hotel windows in protest after the meeting.

After snatching a few hours of sleep, Hardie and Connolly boarded a train for the Transvaal in the early hours of the morning. ${ }^{74}$ The Transvaal labour movement, like their Natal counterparts, were predominantly advocates of white labour protectionism. The major unions had waged a vigorous campaign against the importation of Chinese labour, and the Transvaal Independent Labour Party (TILP) leaned toward racially discriminatory positions. Tom Mathews, the Cornish leader of the Transvaal Miners Association, had deplored Smuts' willingness to compromise with Gandhi, and had supported a boycott of Indian shops, declaring 'Either we are going to make the Transvaal a white man's country or another Natal. ${ }^{75}$ As in the case of Natal though, Transvaal labour leaders' differences with Hardie over racial politics were seen by them as secondary to their loyalty to the British labour movement, and they were more than ready to defend Hardie against his jingoist opponents. Moreover the Transvaal, unlike Natal, had a small minority of immigrant labour activists with an articulate anti-racist position. Archie Crawford, a Scottish engineer who was organizing the unemployed in Johannesburg, had advocated the admission of people of colour to the TILP. He was engaged in launching a militant syndicalist paper, the Voice of Labour, which denounced the 'white labour fraud'. Arthur Brittlebank, an Australian who was a mainstay of the Pretoria TILP, was sceptical of white labourism

\footnotetext{
69 Hale, 'Socialist agitator', p. 12.

70 NLS Dep. 176 vol. 14, J. Edwards, Durban to James Hardie, Cummnock, 15 February 1908.

71 Goolam Vahed, 'Constructions of community and identity among Indians in colonial Natal, 1860-1910: the role of the Muharram Festival', Journal of African History, 43, 2002, pp. 77-93.

72 Hale, 'Socialist agitator', pp. 12-14; Labour Leader, 24 April 1908.

73 Labour Leader, 24 April 1908.

74 Labour Leader, 24 April 1908.

75 The Star, 4 February 1908.
} 
and sympathetic to Gandhi's movement. John Campbell, an Irish-born Clydesider who was a follower of Daniel De Leon, was advocating the unionization of black workers. ${ }^{76}$

As the train approached Johannesburg in the late afternoon of 16 February, a number of TILP members, including Crawford, joined Hardie on board. On they went to the city. The platform at Park Station was filled with a hostile, all-male crowd, drawn from the city's more affluent social strata. ${ }^{77}$ When the train pulled in it was greeted with 'a roar of continuous booing'. Hardie stepped onto the bogie of his carriage intending to speak but the crowd tried to mob him. Five policemen and his little group of supporters rushed Hardie through a side-entrance under a hail of eggs, tomatoes and stones. Crawford and another comrade pulled Hardie aboard a landau, which drove off at great speed with Crawford waving derisively to the crowd. ${ }^{78}$

Driving around the city the next day, Hardie was struck by the impact which the economic depression had had. He found that Milner (although no longer governor) was enormously unpopular with British working-class immigrants, who blamed Milner - rightly in Hardie's view - for their problems. Hardie regarded the proconsul as merely the 'the fly of the wheel of the mine-owners' chariot'. ${ }^{79}$ He noted that many British immigrants were now so alienated by imperial policy that they actually preferred Afrikaner government to direct British rule or the domination of the Progressives, the mine-owners' party. ${ }^{80}$

That night, Hardie tried but failed to address a meeting which had been organized for him at the Johannesburg Caledonian Hall. In attendance were about 1,000 people and a police contingent of 35 . The labourites clustered in the front rows, in order to give Hardie some protection, but their opponents drowned him out with cries of 'Zulu Hardie' and the like. After half-an-hour Hardie gave up trying to speak and the audience burst into 'Rule Britannia'. Hardie was smuggled out of the building to the relative safety of the Langham Hotel. But the crowd, thinking he was still in the hall, refused to leave, took over the stage for speeches from their leaders, and besieged the remaining labour leaders in an ante-room. After two hours the police emptied the hall amidst some violence. ${ }^{81}$

Hardie spoke to the labourites at a meeting at Johannesburg Trades Hall in the evening. Here, in his attempts to win over the audience, he went a long way towards catering to their racial prejudices. Hardie warned white workers against 'lending themselves' to the exploitation of blacks and asserted that he stood for 'equal rights for all men'. But he also gave a nod and a wink to the white labourists' agenda. The danger, said Hardie, was that black workers would take the white workers' place:

He wanted to guard against that; but he wanted to see the highest standard of civilization that had yet been reached maintained, and extended and developed, and if they had to compete with coloured labour it would drag them down to its standard. (Hear, hear) How was it to be guarded against? By saying to the employer that if he was going to employ

76 For the Transvaal labour movement in this period see Ticktin, Origins, vols. 1 and 2.

77 The Star, 17 February 1908.

78 The Star, 17 February 1908.

79 Labour Leader, 24 April 1908.

80 Labour Leader, 24 April 1908.

81 The Star, 18 February 1908. 
coloured labour, in what was now white man's work, he must pay the white man's wage (Hear, hear) - and if he paid that he would prefer the white man all the time. ${ }^{82}$

Hardie also blatantly played to the British workers' sense that the management's importation of Chinese labour had been a racial betrayal. The men who had been loyal during the Boer War, he said, 'did not think that patriotism, when it came to Johannesburg was going to come in a pigtail and a yellow skin'. ${ }^{83}$

From Johannesburg, Hardie proceeded to Pretoria. He liked the town, which was small, quiet and clean, ${ }^{84}$ and was taken with the hospitable Pretoria socialists - several of whom had familiar Scottish labour backgrounds. ${ }^{85}$ Hardie lunched the next day with Botha and Smuts. ${ }^{86}$ Despite their differences over racial politics, he still saw something heroic in the Boer cause of 1899-1902. The first visit he had made in the capital was to the house of the now-deceased Paul Kruger, which had been preserved as a museum. ${ }^{87}$

On Hardie's last evening in the capital though, the onslaught against him reached its high point. Facing a politically divided meeting in the Town Hall, Hardie managed to struggle through his speech despite extensive heckling and fighting in the back of the hall. But as the meeting ended, he found himself trapped by an angry mob of about 3,000 people, who were being held back by a police cordon. After some time the police got Hardie into a cab, which raced away with the crowd in pursuit. The driver took a circuitous route to Hardie's hotel, and by the time he arrived there, the crowd had re-assembled outside. Hardie was rushed inside while objects were hurled at him. After waiting around singing 'We'll hang Keir Hardie from a sour apple tree' the crowd dispersed. ${ }^{88}$

\section{Homeward: February-March 1908}

The Pretoria incident marked the end of Hardie's South African travails. Moving south to Basutoland, he met the Resident Commissioner and Basuto chiefs, and in the Orange River Colony, Bloemfontein's miniscule Labour Party mounted a surprisingly large and enthusiastic public meeting for him. ${ }^{89}$ Heading down the railway line into the Cape Colony, Hardie stopped at the town of De Aar, where he visited the writer Olive Schreiner, who gave him a gloomy and prescient view of the South African future as one of intractable racial oppression. ${ }^{90}$

At last Hardie arrived in Cape Town, from where he would sail for home. The local Labour Party ignored a previous invitation they had issued to Hardie to visit, for they

82 The Star, 19 February 1908.

83 The Star, 19 February 1908.

84 Labour Leader, 24 April 1908.

85 The Star, 20 February 1908.

86 NLS Dep. 176 vol. 14, Hardie, Pretoria, to Mrs Hardie, Cummnock, 21 February 1908.

87 NLS Dep. 176 vol. 14, Hardie to James Hardie, Cummnock, n.d.

88 The Star, 21 February 1908.

89 Ticktin, Origins, vol. 1, p. 353.

90 Labour Leader, 22 May 1908. 
were in the midst of an election campaign, and feared that his controversial presence would lose them votes. The more radical socialists of the Social Democratic Federation stepped into the breach, and organized successful, and undisrupted, private and public meetings for Hardie. The local Indian community presented him with an address hailing his championship of 'the rights of British Indians throughout the Empire'. 91

Hardie approved of the fact that some Cape Town unions were open to members of colour, and thought that the Cape's property-qualified but non-racial franchise might provide a model for the democratization of the other South African colonies. In his reflections on his southern African stay, he wrote:

Is ['the native'] to be recognised as a human being and allowed to vote and own property, or is he to be treated as being part wild beast and part child? Shall the Cape take from the natives the rights they possess or shall Natal, Orangia and Transvaal adopt the Cape Standard $?^{92}$

Hardie's stance on South Africa was one which sought to reconcile the interests of the existing white unions and labour parties with the egalitarian, humanist imperatives of his own ethical socialism. Typically, he argued that:

Socialism stood for the rights of Humanity as human beings, and if the white working people countenanced the exploitation of the coloured races then they themselves must expect to be exploited. ${ }^{93}$

But self-interest and altruism were not so easily brought together. In the end, of course, the white working class did find the racialized protection of their interests an effective strategy, and turned their backs on ideas of universal labour solidarity.

\section{Conclusion}

The ramifications of Hardie's journey extended long after his visit. He certainly played an important role in shifting British Labour toward a more active, knowledgeable and critical engagement with colonial issues. The publication of his book on his Indian experiences was an important contribution in this direction. His lead was followed by Labour's rising star, James Ramsay MacDonald, who also travelled to India and produced a book on the subject of imperial policy there. ${ }^{94}$ Hardie took up Indian issues in the House of Commons, starting with a demand for Tilak's release after the swadeshi leader was jailed in $1908 .{ }^{95} \mathrm{He}$ developed a similarly active interest in southern Africa, for example assisting the missionary Edouard Jacottet in his successful campaign to prevent the incorporation of Basutoland into the Union of South Africa. ${ }^{96}$ Hardie can claim some of the credit for moving a wing

91 Cape Times, 2 March 1908.

92 Labour Leader, 5 May 1908.

93 Cape Times, 2 March 1908.

94 J. Ramsay MacDonald, The awakening of India, London: Hodder and Stoughton, 1910.

95 Morgan, Keir Hardie, p. 193.

96 Tim Couzens, Murder at Morija, Johannesburg: Random House, 2003, pp. 309-10. 
of the southern Africa white labour activists toward a more non-racial position. In Natal, Connolly, apparently as a direct result of Hardie's influence, broke with Haggar and Palmer's racial politics to oppose the racist legislation against Indians and to denounce the prosecution of Dinuzulu. ${ }^{97}$ Although Hardie's influence on the Transvaal was not so direct, his visit certainly gave support to the critique of white labour protection which was being developed by some Transvaal radicals, and which later fed into the 1915 leftist breakaway from white labourism of the International Socialist League.

More broadly, what the controversy around the Hardie trip illustrates is the multi-sided discursive struggle over imperial citizenship in this era, in which Indian nationalists, diasporic British labour, new settler-state leaderships, and the contending political factions at the imperial centre were all involved. The most conservative factions in British politics used Hardie's statements not only to head off the pressure for Indian political rights, but also to cast retrospective doubt on the wisdom of allowing working-class representatives into Westminster. Swadeshi activists took Hardie's backing, and his equation of their cause with the established practice of Canadian self-government, as a significant legitimation for their demands. In Transvaal, the newly emerged Gandhian movement could use the desire of the Viceroy's government to be seen in India as defending diasporic Indians to place pressure on London to check the restored Boer government's depredations against Indian rights. The white working-class leaders of southern Africa and Australia pressed their claim for recognition of rights based on racial identity. Yet in the particular circumstances of Hardie's visit, the South African labourites placed their connections to British labour before their racial ideology. In a world where it was by no means apparent to contemporaries that the new century would see the demise of the British Empire, the war of position within the imperial polity seemed, to all but a few extreme radicals, the only one to play. At stake was whether imperial citizenship would be defined in racial terms. The imperial working class and a globalized Indian political nationalism were making claims as major contenders in this struggle.

Jonathan Hyslop is Deputy Director of the Wits Institute for Social and Economic Research (WISER), University of the Witwatersrand, Johannesburg.

97 Ticktin, Origins, vol. 1, pp. 382-7. 